\title{
Dynamika recepce Smetanovy tvưrčí osobnosti a jeho operního díla do roku 1924
}

\section{Dynamics of Reception Studies of Smetana's Creative Personality and His Opera Works Until 1924}

\author{
Kateřina Viktorová / katerina.viktorova@nm.cz \\ Bedřich Smetana Museum, National Museum, Praha, CZ
}

\begin{abstract}
While observing the dynamics of the reception studies of Smetana's creative personality and his opera works, several cultural-social as well as political milestones appeared which transformed society as well as its aesthetic needs, provoked diverse discussions about the composer's works and its influence on Czech national music and gave a new direction to the reception studies. They included, for example, the conflict between Old Czechs and Young Czechs, the premiere of Smetana's first operas, Wagner's musical reforms, the opening of the Provisional and National Theatre, Smetana's deafness and death, the International Exhibition of Music and Theatre in Vienna, the First World War, the establishment of an independent Czechoslovak state and the celebrations of the anniversary of Smetana's birth. It is characteristic of Smetana's works that they were not received unambiguously both during his life and later and he himself did not immediately become a generally accepted and recognized personality. Although during his life he received society-wide renown from both the Czech lay public and experts and he was recognized as the reformer of Czech musical life and music and the creator of their modern forms, which has not been questioned since, the process of discovering and understanding his works to their full extent was long. The thesis provides a basic description of how the perception of Smetana's creative personality and works developed and the dynamics it acquired from the first reflections during his life until 1924, when extensive celebrations of the $100^{\text {th }}$ anniversary of the composer's birth took place, which are until today considered the absolute climax of the activities celebrating Smetana, which have not been surpassed in terms of intensity and quality until the present day.
\end{abstract}

Studie vznikla v rámci projektu řešeného s podporou Grantové agentury ČR (č. 20-19382S): Bedřich Smetana. Korespondence III (1875-1879). Kritická edice. Tématu se věnuje také jedna z kapitol disertační práce VIKTOROVÁ, Kateřina. Pražská recepce Smetanových oper 1900-1924. FF MU, Brno 2020, 243 s. 


\section{Key words}

Reception studies, Bedřicha Smetana, Smetana's Operas, Music Battles about Smetana, National Theatre in Prague, The International Exhibition for Music and the Drama

Při sledování dynamiky recepce Smetanovy tvưrčí osobnosti a jeho operního díla vystupuje do popředí několik kulturně-společenských i politických mezníků, které proměňovaly společnost i její estetické potřeby, podněcovaly rozličné debaty o skladatelově díle i vlivu na českou národní hudbu a udávaly jeho recepci nový směr. ${ }^{1}$ Operní dílo Bedřicha Smetany poutalo pozornost již od skladatelovy prvotiny. Př́ičinu lze spatřovat v postavení opery, která v 19. století zaujímala v hierarchii uměleckých druhů prestižní pozici a díky tomu, že v ní bylo možné uplatnit národní jazyk a reflektovat témata z národní historie, se stala hlavním předmětem zájmu skladatelů, kteří své tvůrčí cíle spojili s národní hudbou. Důležitou roli hrálo také postavení samotného skladatele. Na počátku šedesátých let se jako pedagog, sbormistr, dirigent i skladatel aktivně zapojil do obrozujícího se českého kulturního života a brzy se stal jednou z jeho nejvýraznějších postav.

Pro Smetanovu tvorbu je příznačné, že za jeho života ani později nebyla přijímána jednoznačně a on sám se nestal okamžitě všeobecně akceptovanou a uznávanou osobností. Do vnímání skladatelova díla vstoupily v první polovině sedmdesátých let 19. století vzrušené polemiky vedené v denících i odborném tisku, později označované jako „boje o Smetanu“. Svůj základ měly v uvedení Smetanovy opery Dalibor v roce 1868. Zahájení provozu Prozatímního divadla v roce 1862 otevřelo otázku definování české národní opery a české hudby vủbec. Ve stejné době uváděl Richard Wagner svá vrcholná díla a v celé Evropě se rozpoutala debata o Wagnerových hudebních reformách, která se do recepce Smetanovy tvorby významně promítla. Konec šedesátých a začátek sedmdesátých let 19 . století byl dobou polemik o Wagnerovo hudební drama, a především o podobu české národní opery. Pro ni bylo podle Otakara Hostinského Wagnerovo hudební drama idea hodná následování - pokud „se díla chápe velká, silná individualita duchem národním oživená, která to, co bere odjinud, dokonale umí ovládati, sobě osvojovati a prizprisobovati“, ${ }^{2}$ není se třeba obávat epigonství. Takovou individualitu Hostinský spatřoval ve Smetanovi. Některé specifické hudebně-dramatické prostředky objevující se ve Wagnerových operách se však staly terčem kritiky a jako takové začaly být označovány za wagnerovské. Pro odpůrce wagnerovského směru, ${ }^{3}$ k nimž patřil především František Pivoda, bylo naopak

\footnotetext{
1 Smetanovské recepci se věnovala Olga Mojžíšová, která stručně pojednala v základních etapách vývoj a proměny recepce Smetany a jeho hudby, viz MOJŽǏŠOVÁ, Olga. Odkaz Bedřicha Smetany - vývoj a proměny jeho recepce. In Národni identita/y. Praha: Institut umění - Divadelní ústav - Česká hudební rada, 2012, s. 39-45. Dále také SÉQUARDTOVÁ, Hana. Sto let Smetanova tvưrčího odkazu. In KUNA, Milan (ed.). Sto let odkazu Bedřicha Smetany. Přispěvky a studie z konference hudebně vědecké oblasti Svazu českých skladateli̊ a koncertnich umělců v Praze. Praha: Svaz českých skladatelů a koncertních umělců, 1985, s. 105-112; FUKAČ, Jiří - PAVLÍČKOVÁ, Jana. Sémantická otevřenost jako faktor recepce Smetanova díla. In Kuna 1985, op. cit., s. 133-146; a BERKOVEC, Jiří - JIRÁNEK, Jaroslav - SMOLKA, Jaroslav. Reflexe Smetanova díla a odkazu. In Kuna 1985, op. cit., s. 93-104.

2 HOSTINSKÝ, Otakar. Česká hudba 1864-1904. Praha 1909, s. 16.

3 Wagnerovský směr (také wagnerismus) znamená vliv Wagnerova díla a jeho názorů na rozmanité myšlen-
} 
následování Wagnera nežádoucí, protože principy opery údajně popíral tím, že její hlavní dramatický prostředek, zpěv, byl potlačován orchestrem, který navíc znemožňoval se v díle orientovat. Příznivci wagnerovského směru volali po české variantě hudebního dramatu, čímž by se česká opera dostala na údajnou špičku evropského pokroku. Deklamační styl Wagnerových pěveckých partů pokládali za ideální způsob, jak pomocí deklamace českého textu dostat do opery národní ráz.

Boje o Smetanu ovšem nebyly vedeny jen v rovině umělecké, jejich předmětem se staly také spory o vedení opery i osobní averze, a vstupovala do nich i politická rivalita. Spory o Smetanovy aktivity byly součástí politického boje mezi staročeskou a mladočeskou frakcí, které mezi sebou mimo jiné soupeřily o vliv v Prozatímním divadle, jedné z nejvýznamnějších národních institucí té doby. Smetana se hlásil k mladočeské skupině. Jeho odpůrci se soustřed’ovali ve staročeské straně. Jedním z jejích vůdců byl František Ladislav Rieger a v uměleckých otázkách byl považován za Smetanova oponenta. ${ }^{4}$ Prosmetanovské články vycházely zejména v mladočeském deníku Národní listy. Protismetanovské příspěvky potom ve staročeských listech Pokrok, Osvěta a v německy psané Politik. Hudební listy, založené v roce 1870, patřily původně mezi Smetanovy zastánce. Když je však koncem roku 1872 převzal J. S. Skrejšovský, šéfredaktor listu Jan Ludevít Procházka odešel a nahradil jej F. Pivoda. Největší polemiky poté probíhaly právě mezi Pivodovými Hudebními listy a Procházkovým nově založeným časopisem Dalibor. ${ }^{5}$ Význam Procházkových referátů byl spatřován v tom, že v nich „poprvé slovy prístupnými, bez jakýchkoli schemat esthetických, avšak se vš́ rozhodnosti neznajici kompromisů vyslovena byla theorie moderni zpěvohry české, že v nich poprvé vykázáno Bedřichu Smetanovi misto tvưrce a zakladatele této zpěvohry. "6

Procházka, který patřil do okruhu Smetanových spolupracovníků (což mu ovšak nebránilo v projevování i kritických názorů) a jehož referáty o Smetanových operách byly vůbec prvními kritickými reakcemi na Smetanovo operní dílo, opeře Dalibor vytýkal některé pro Wagnera typické skladebné prvky, např. že „dlouhé, často symfonické rozpřádáni motivĩ, jichž [...] několik základnich ku karakterisováni jednotlivých osobností použil“,7 se děje na úkor dramatičnosti. Zdrženlivost obecenstva vưči Daliboru byla částí kritiky interpretována jako kampaň Smetanových odpůrců proti tomu, že se vydal na cestu nenárodní - na cestu Wagnerovu. Tato polemika se veřejně otevřela v roce 1870 , kdy

\footnotetext{
kové proudy a tvorbu (nejen hudební) jednotlivých umělců, či dokonce uměleckých směrů. Přívrženci wagnerismu byli označováni jako wagneriáni. Smetanu nazývali wagneriánem v negativním kontextu jeho odpůrci již od premiéry opery Braniboři v Čechách v r. 1866.

4 Důvody konfliktů mezi Smetanou a Riegrem osvětluje brožura NEJEDLÝ, Zdeněk. Bedřich Smetana a kulturní politika F. L. Riegra, Praha: Melantrich, 1915. Kniha BRÁFOVÁ, Libuše. Rieger, Smetana, Dvořák. Praha: Fr. A. Urbánek, 1913, dcery F. L. Riegra, se pokusila uvést z jejího pohledu na pravou míru přístup Riegra ke Smetanovi. Češství Smetanových děl i roli F. L. Riegra, kterou v této otázce sehrál, se věnuje stat HNILIČKA, Alois. B. Smetana a spory v letech sedmdesátých o češství děl jeho. In Rozhledy po životě a významu Bedřicha Smetany. Praha: Mojmír Urbánek, 1924, s. 107-120.

5 V lednu 1973 byl založen „druhý“ Dalibor, „první“ Dalibor vycházel s přestávkami od 1858, redigoval ho E. A. Meliš.

6 LÖWENBACH, Jan. První apoštol hudby Smetanovy. Hudebni revue, 1908, roč. 1, č. 7, s. 340.

7 P. [PROCHÁZKA, Ludevít]. Dalibor. Národní listy. 18. 5. 1868, roč. 8, č. 137, s. 3.
} 
Pivoda za důvod, proč Dalibor, ,jemuž by už lépe slušelo jméno ,Dalibor Wagner “,, u publika propadl, označil Smetanovo záměrné opouštění dosavadní cesty vedoucí k národnímu umění. Jako obranu Smetany před útoky skupiny okolo F. Pivody vypracoval Hostinský na základě svých estetických principů a s ohledem na aktuální wagnerovské polemiky analýzu Smetanova Dalibora, ${ }^{9}$ jejímž hlavním cílem bylo vyvrácení Smetanova obvinění z wagneriánství jako tvůrčího epigonství a naopak doložení národního rázu jeho hudby.

Polemiky vyvrcholily v první polovině let sedmdesátých, kdy bylo Smetanovi předhazováno wagneriánství i ve Dvou vdovách. „Výšku muže sáhodlouhého obdivujem; strhneme však hlasitý smich nad bláznem, který jej považuje za věž. Kdybychom nebyli tak okřičeni tím reklamnim hlukem, jakého pokaždé nadělaji přátelé našeho Smetany, [...] bůh ví, co jest dokonalého na jeho nejnovějši komické opeře ,Dvě vdovy“ [...] Smetana, co čelní zastávatel směru Wagnerovského, přidělil $i$ zde hlavni podil orkestru, který vede prvni slovo. [...] S českým živlem zpěvnim nepotkáváme se než ve dvou sborech, z nichž proni zavzni na začátku, druhý ku konci opery. "10 Od března 1874 se v divadelním družstvu odehrával nový boj o Smetanovo kapelnické místo. Dvě vdovy se staly také předmětem Smetanova sporu s novým ředitelem Prozatímního divadla Janem Nepomukem Maýrem. Ozývaly se ale také hlasy, které Smetanův tvưrčí př́ístup hájily. „Chtěli jsme čtenářstvu svému podati aspoň náčrtek z,Libuše Smetanovy, tohoto vzoru vážné české národni zpěvohry, aby každý přesvědčiti se mohl, po jak vznešených drahách kráči ku předu Smetanův genius. Mnohý snad se vynasnaži, aby zvláště z tak zvaných ,motivů př́značných“ vyčenichal cosi, Wagnerovského. ' [...] komu se dostalo vzácné té přlležitosti, aby pohlidnouti mohl v partituru,Libuše', musi uznati, že neslyšel dosud češtějši a při tom na stupni nejmodernějším stojicí než v této skladbě - ano že vlastně teprvé při této zpěvohře po právu mluviti můžeme o ,̌eské hudbě.."11

Smetanovi byly vytýkány i nejrůznější kroky spojené s provozem divadla - nedostatečné vedení souboru, prosazování vlastních oper na úkor jiných českých autorů, proněmecká orientace repertoáru, vysoké gáže ad. Smetanovi sympatizanti označovali v tisku skladatelovo onemocnění za následek „neustálého rozčilování, jakých mu v posledni době spuisobováno bylo s jisté strany“, ${ }^{12}$ a stylizovali ho tak do role mučedníka. Objevily se však i ostré útoky Smetanových oponentů, kteří se vysmívali jeho „neslýchanému lazarstvi“, ${ }^{13}$ a vyčítali mu také penzi, kterou mu divadlo přiznalo. „[...] das Publikum dürfte ihn [Smetana] eher vom Caffé Bendl aus kennen, wo er den ganzen Tag hiadurch seine Zeitungen ließt, wenn er nicht gerade zu Hause seine irritirten Nerven kurirt. Seine ganze körperliche Konstitution soll durch die derouten Theaterverhältnisse derart angegriffen sein, dass er den Taftirstab gar nicht sehen, geschwerge denn Proben abhalten kann. [...] Dies die erste Persönlichkeit, die

8 PIVODA, František. Hovorna. Panu Bedřichu Smetanovi, prvnímu kapelníku české opery. Pokrok, 3.3. 1870 , roč. 2 , č. 61, s. 3 .

9 Rozbor vycházel v časopise Dalibor na pokračování od 14. 2. do 28. 3. 1873. Také vydán in HOSTINSKÝ, Otakar. Bedřich Smetana a jeho boj o moderní českou hudbu. Vzpominky a úvahy. Praha: Jan Laichter, ${ }^{1} 1901,{ }^{2} 1941$, s. 233-268.

10 tt. Česká opera. Hudebni listy, 1874, roč. 5, č. 16. s. 68.

11 X. Zpěv Přemysla. Dalibor, 1874, roč. 2, č. 6. s. 45.

12 [?] Zprávy z Prahy a z venkova. Dalibor, 1874, roč. 2, č. 33, s. 262.

13 [?] Zprávy domácí a z venkova. Hudebni listy, 1874, roč. 5, č. 34, s. 138. 
das böhmische Theater für eine Versorgungsanstalt, ein Invalidenhaus und für ein pahologisches Institut ansteht. " 14 Hrubost těchto komentářů veřejnost odsuzovala. Na Smetanovu stranu se postavil také Jan Neruda. „Nevite, komu že mistr Smetana v Čechách překážr? Povídá se sice, že překáži panu Pivodovi, pak také, že jakémus panu Böhmovi [...]. Ale to snad neni možná, aby Smetana překážel pánům těm. Což pak překáži Petřín některému z těch oblázků, které leži dole na břehu Vltavy?"15 V roce 1875 obě hlavní platformy smetanovských bojů, Hudební listy i Dalibor, zanikly a ve druhé polovině sedmdesátých let především v souvislosti se Smetanovým ohluchnutím a jeho odchodem z divadla boje o Smetanu výrazně zeslábly.

Výrazným impulsem pro pražský divadelní život bylo otevření Národního divadla 11. června 1881, nejdůležitější české kulturní instituce a v rovině politické symbolu českého národního hnutí, ale také uměleckého ústavu s velkou mezinárodní autoritou prezentujícího před evropskou veřejností vyspělou kulturu. ${ }^{16}$ Provoz Národního divadla zahájila očekávaná premiéra Smetanovy slavnostní opery Libuše,${ }^{17}$ která představuje jeden z mezníků, jenž měl vliv na proměnu recepce Smetanovy tvorby. Premiéra vzbudila velký zájem tisku, který se hojně věnoval Smetanovu dílu. Došlo ke krátkodobé aktualizaci smetanovských bojů, utlumených od poloviny sedmdesátých let, které však po uveřejnění několika článků utichly. Část kritiky se nevyhýbala zmínce o vlivu Richarda Wagnera a jeho reforem či o Smetanově wagnerianismu a vyzdvihovala stopy Wagnerovy operní reformy v Libuši, díky nimž představovala dosud nejmodernější českou vážnou operu. Zároveň to ale neznamenalo, že by Smetana jako wagnerián u nás zaváděl německý směr. ${ }^{18}$ "Tím, že Smetana Wagnerův princip, stanovici požadavky hudby dramatické, prījal za svůj, prospěl velice zpěvohře české; zdravý Wagnerism, jak Smetana zastává jej ve své ,Libuši ‘, jest rovněž tak záslužný jak pováżlivý, ba zhoubný jest onen, který ve znetvořni zdravého principu a v otrockém povždy málomocném pitvořeni se po typické hudebni povaze Wagnerově, spatřuje spásu moderni opery. [...] Smetanovo dilo, [...] prosto jest povážlivého napodobováni kteréhokoliv cizího, tedy $i$ Wagnerovského hudebního slohu. Typická tvár Smetanovy musy neztratila ve vážném výraze, jaký jeví v ,Libuši , v ničem své zajímavosti, a národni ton [...]." ${ }^{19}$

Sám Smetana pokládal Libuši „za nejdokonalejši práci v oboru vyššiho dramatu, [...] za úplně samostatné dilo (weder Wagner noch Offenbach ${ }^{20}$ ). “21 Wagnerův vliv v Libuši byl spatřován

14 „[...] obecenstvo ho [Smetanu] zná spíše z kavárny Bendl, kde celý den čte své noviny, pokud si zrovna doma neléč́ své podrážděné nervy. Celá jeho tělesná konstituce byla divadelnimi poměry údajně do té míry poškozena, že taktovku nemůže ani vidět, natož pak pořádat zkoušky. [...] Jedná se o prvni osobnost, která české divadlo pokládá za zaopatřovací instituci, invalidovnu, za patologický ústav." [?] Vom böhmischen Theater. Belehrendes und Unterhaltendes. II. Politik, 13. 9. 1874, roč. 13, č. 251, s. [2].

15 [NERUDA, Jan]. Feuilleton. Národni listy, 28. 2. 1875, roč. 15, č. 58, s [2].

16 Divadlo tehdy neslo název Královské zemské české divadlo.

17 Smetana ji zkomponoval již o deset let dříve, v letech 1871-1872.

18 Soustředěný pohled na recepci Smetanovy Libuše při její premiéře v roce 1881 přinesl PECHAČ, Marek. Reflexe díla Richarda Wagnera v osmdesátých letech 19. století v českých zemích. FF UP, Olomouc 2011. Diplomová práce, s. 37-49.

19 CHVÁlA, Emanuel. Otevření Národního divadla. Dalibor, 1881, roč. 3, č. 18, s. 140.

20 [ani Wagner, ani Offenbach]

21 Smetana L. Procházkovi, dopis z 26. 9. 1877, viz Fond Bedřicha Smetana, Národní muzeum - Muzeum Bedřicha Smetany, S 217/291. 
v přijetí zásad hudebně-dramatického výrazu a v ideálu stylové jednoty. Skladatel se však nenechal strhnout $\mathrm{k}$ „asketickému odřikáni se melodie, $k$ prebujeni deklamace, $k$ vymýtěni sbori̊ a $k$ naprostému rozbiti uzavřených čísel. "22 Vyhnul se úskalím, kterým se Wagner při důsledném dodržování zásad svého hudebního dramatu vyvarovat nedokázal - „únavným délkám, zbytečné rozbředlosti, nedostatku sytých kvetoucich melodii a beztvaré, měkkýšovité rozplývavosti. "23 Později se Smetana vůči kritickým názorům v tisku obhajoval jako umělec jdoucí svou cestou. „Já nepadělám skladatele slovutného žádného, já jen se obdivuji velikosti jejich a vše přijimám pro sebe, co uznám za dobré a krásné v uměni, a predevším pravdivé. [...] mysleji, že zavádím Wagnerismus!!! Mám dost co dělat se Smetanismem, jen když ten sloh je poctivej!“ 24

Definitivním otevřením Národního divadla v roce $1883^{25}$ začalo „nové obdobi českého uměni dramatického“. ${ }^{26}$ Češi měli konečně reprezentativní divadlo evropského formátu. Základ repertoáru viděl ředitel František A. Šubert v české tvorbě. Prvních šest týdnů mezi 11. listopadem 1883, kdy byl provoz Národního divadla znovu Libuši zahájen, a koncem roku se zde hrál pouze český repertoár, včetně osmi českých oper. Prodaná neveesta a Hubičk byly standardní součástí repertoáru, Libuše se na scéně Národního divadla při slavnostních příležitostech objevovala každý rok. Dvě vdovy a Tajemstvi nevzbudily takový zájem. Stejný osud potkal Branibory v Čechách i proto, že v osmdesátých letech již publikum nejevilo takový zájem o národní témata jako o dvacet let dříve. Dalibor se kromě pouhých tří představení v roce 1879 nehrál od roku $1871 .{ }^{27}$ Tehdy sice u obecenstva existovalo jakési vlastenecké nadšení, české opery už ale tolik netáhly. Proto Šubert před „národně-vzdělávacím“ repertoárem mnohdy dával přednost hrám, které i navzdory nižší umělecké hodnotě zaručovaly plné hlediště, a tudíž i plnou pokladnu. ${ }^{28}$ Šubertovi bylo vytýkáno zanedbávání domácí operní tvorby, pohostinská vystoupení zahraničních hvězd jen pro finanční zisk, povrchnost repertoáru a údajný akcent na okázalost, která odváděla pozornost diváků od samotného díla. „Tu pak najdeme, čeho bychom se před otevřnim Národního divadla ani ve snu byli nenadáli, v repertoaru proního roku: Lucrezii Borgii, Lucii, Troubadoura, Maškarni Ples, Afričanku, Martu a představeni smišené ze tř́ jednáni ri̊zných zpěvoher! [...] Takový byl r. 1884 umělecký vkus v Čechách, [...] takový byl národní ráz divadla v samých počátcích, že v prvnich měsicich neobešlo se bez nejobehranějšich cizich škvárü [...]." ${ }^{29}$ Kritika žádala repertoár založený na častějším provozování českých (zvláště Smetano-

22 KREJČí, František Václav. Bedřich Smetana. Praha: Pelcl, 1900, s. 104.

23 KREJČÍ 1900. Op. cit., s. 105.

24 Smetana A. Čechovi, dopis ze 4. 12. 1882, viz Fond Bedřicha Smetana, Národní muzeum - Muzeum Bedřicha Smetany, S 217/220. Smetanismus (smetanovský sloh) je dobovou alternativou výrazů wagnerismus či wagnerianismus, která zdůrazňovala stylovou svébytnost díla (zvláště oper) Bedřicha Smetany. Do hudebně-publicistického a muzikologického prostředí pronikl tento výraz až po roce $1900 \mathrm{v}$ souvislosti s diskuzemi o povaze Smetanova individuálního stylu. Viz HOLUBOVÁ, Eliška. Smetanismus. In FUKAČ, Jiří - VYSLOUŽIL, Jiří (red.). Slovnik české hudebni kultury. Praha: Editio Supraphon, 1997, s. 1014.

25 Po znovuotevření divadlo neslo název Královské české zemské a národní divadlo.

26 HOSTINSKÝ 1941, op. cit., s. 340.

27 Provozování a recepci Smetanových oper v období 1866-1900 sledoval HOSTINSKÝ, Otakar. Zevnější úspěchy zpěvoher Smetanových. In HOSTINSKÝ 1941, op. cit., s. 440-449.

28 V sezónách 1883/1884 - 1888/1889 klesl počet večerů s původní českou tvorbou z 90 na 33 představení.

29 [ZELENÝ, Václav Vladimír] První rok v Národním divadle. Dalibor, 1884, roč. 6, č. 44, s. 434. 
vých) oper, nazkoušených s př́íslušnou péčí. Šubert reagoval tvrzením, že publikum si žádá přesně takový program, který Národní divadlo provozuje. Upozorňování na nepříliš časté uvádění původní české tvorby, která již sama o sobě byla považována za hodnotu a které se má Národní divadlo věnovat především, se objevovalo od samotných počátků fungování Národního divadla. Postupný úbytek českého repertoáru dokumentují tyto statistiky: zatímco v prvním půlroce po otevření Národního divadla zabírala česká produkce $63,9 \%$ repertoáru, ve druhém to bylo již jen $38,9 \%$ a ve třetím pouhých $28,7 \% .^{30}$ $\mathrm{V}$ roce 1886 se situace české opery začala obracet k lepšímu, u Smetanových oper především díky úspěchu nové inscenace opery Dalibor. ${ }^{31}$

Po Smetanově smrti 12. května 1884 se v souvislosti s jeho lidským osudem objevily dva myšlenkové postoje. Byl přijímán na jedné straně jako mučedník a obět své hudební geniality a na straně druhé jako hrdina, čelící osudovým ranám, nakonec však podléhající. Smetana ale nebyl významným umělcem proto, že trpěl, nýbrž proto, že vytvořil progresivní díla. „Smetanismus znamená především nebojácný hudebni výboj, odvážný pokrok, který sice se opírá o tradici, ale nikoliv proto, aby v ni měl di̊vod pro pohodlnické setrváváni $v$ naučené skladatelské metodě, nýbrž naopak, aby v ní našel výzbroj pro dalš́ organický, ale zároveň energický vývoj. " ${ }^{32}$ Brzy po skladatelově úmrtí se v českých hudebních kruzích začaly objevovat snahy o zrrízení instituce, která by osobnosti Bedřicha Smetany vzdala hold, jakož i hlasy volající po zhodnocení jeho odkazu a významu pro českou hudbu formou obsáhlé a ucelené monografie. ${ }^{33}$ Za nejpovolanějššiho potenciálního autora Smetanovy monografie byl tehdy označován Otakar Hostinský, který však vzhledem k objemu práce i k malému časovému odstupu ještě nepovažoval takovýto projekt za reálný. „Vždyt’ dnes - a to je moje pevné presvědčeni - neni ještě ani možno, ani na čase, vylićiti ve formě obsáhlé biografie Smetanovy celý běh života jeho a to, co nerozlučně s ním je spojeno: rozvoj hudebního uměni v Čechách za více než padesát poslednich let. Nyní prozatím nemůžeme činiti nic jiného, než snášeti co možná nejhojnějši materiál $k$ dílu takovému. "34 Prameny se nalézaly v soukromých rukou, přístup k nim byl tudíž omezen a jen díky vstřícnosti jejich vlastníků se je od osmdesátých let dařilo spíše nárazově uveřejňovat. V té době bylo tedy nejdůležitějším úkolem nejprve smetanovské prameny a informace ke Smetanovu životu, dílu i době shromažd’ovat a následně zpřístupňovat.

30 KADLEC, Petr. Pražská recepce Smetanových oper 1884-1900. Univerzita Karlova. Filozofická fakulta, 2006. Magisterská diplomová práce, s. 85.

31 „Vítězství“ opery bylo podle Hostinského způsobeno jednak vydáním klavírního výtahu v roce 1884, který umožnil širší veřejnosti se $s$ dílem blíže seznámit, a také vhodným výběrem interpretů a proměnou recepce Smetanova díla po skladatelově úmrtí.

32 HELFERT, Vladimír. Cesty za novým stylem. Otázka Smetanovy tradice. In Vybrané studie I. O hudební tvořivosti. Praha: Editio Supraphon, 1970, s. 270.

33 V době skladatelova úmrtí byly publikovány pouze dílčí biografické statě, vzniklé na základě Smetanových přímých, a tedy autentických informací.

$34 \mathrm{Z}$ předmluvy Otakara Hostinského k projektu postupného vydávání Smetanových dopisů, které vycházely v Daliboru v letech 1885-1887. Viz [HOSTINSKÝ, Otakar] Smetanovy dopisy. Dalibor, 1885, roč. 7, č. 18-19, s. 174. 
Významnou úlohu v prosazování Smetanova operního díla sehrálo mimořádně úspěšné uvedení oper Prodaná nevesta a Dalibor na Mezinárodní hudební a divadelní výstavě35 ve Vídni konané v roce 1892. Během příprav zájezdu Národního divadla nejprve panovaly jisté pochybnosti a mezi ředitelem divadla F. A. Šubertem a ostatními účastníky vyvstaly spory. ${ }^{36}$ Proti Prodané nevěstě jako českému zahajovacímu představení se stavělo správní Družstvo Národního divadla s tím, že před velkoměstským publikem obstojí lépe Dvořákův Dimitrij než tento „kousek života ze zastrčené české vesnice“. ${ }^{37}$ Své pochybnosti nezastírala ani česká žurnalistika, která je prezentovala prostřednictvím satirických kreseb a glos. Tvrdila, že se Národní divadlo chystá do Vídně s vesnickou operou, s koktavým Vaškem a směšným Kecalem, a že vídeňské časopisy se jen hemží vtipy na „bohemáky“, jimž na humoristických obrázcích čouhá sláma z bot. „Obecenstvo naše, oslněné při cizich, zuláště Meyerbeerouských, operách zevním leskem a hlavně ,rytírskými“ kroji těch děl, domnivalo se, že naše prosté kroje národní, naše ,koženky“, předem v cizině odradi. “38 Přehlídka, konající se od 7. května do 9. října 1892 v parku Prater, byla rozdělena po vzoru světových výstav podle jednotlivých národi̊ do pavilonů, v nichž byly prezentovány hudebniny, hudební nástroje, dokumenty, portréty. Probíhaly zde rovněž koncerty a další hudební akce. Nakonec ze Smetanových oper byla čtyřikrát provedena Prodaná nevěsta a dvakrát Dalibor. ${ }^{39}$ Představení dosáhla úspěchu nejen u vídeňské kritiky, ale i u publika, které si vynutilo další reprízy. „Vídeňské publikum bylo po roce 1890 unaveno hašteřením wagneriánů, resp. bruckneriánů a brahmsiánů, a zaskočeno raketovým nástupem italských veristi̊, s jejichž díly se rovněž poprvé setkalo u př́ležitosti výstavy. Mascagniho aktovka Cavalleria rusticana opanovala rázem evropská jeviště. Prodaná nevěsta představovala vedle ni onen vesnický svět, jaký měl podle představ vídeňského publika zůstat zachován. Sice se v něm vyskytuji podvodničci a intriky, vitězi však zdravý rozum a láska bez krve a násili." “40

I když vídeňský úspěch Národního divadla znamenal v jistém směru zlepšení pozice českého národa v Rakousku-Uhersku, pokud jde o jeho vnímání v dlouhodobějším horizontu, ozývaly se z řad českých novinářů spíše opatrné hlasy. „Ne snad, že by pan hrabě Taaffe zejtra v politice zahnul k vůli výborné hudbě, ve které se našinci tak osvědčili, anebo proto, že naši herci také už dovedou v řeckém plášti ruce zvedat. Ale př́mluvč́ho jsme ziskali v širokém miněni obecenstva a v tom je posila. [...] Videňské obecenstvo tleskalo a jaká je těsná souvislost všech lidských věcí, ten potlesk má pro nás slibný, politický zvuk. "411 Svědectví o mimořádném

35 Die Internationale Ausstellung für Musik- und Theaterwesen.

36 Více viz ŠUBERT, František Adolf. K výpravě Národního divadla do Vídně roku 1892. Dalibor, 1909, roč. 31 , č. 29-36, s. 48 .

37 PACLT, Jaromír. Vídeň 1892 - most do světa. Divadelni revue, 1994, č. 2, s. 35.

38 ŠUBERT, František Adolf. Feuilleton Smetanovský. Národni politika, 29. 4. 1915, roč. 33, č. 118, s. 2.

39 Dále se uváděl zmíněný Dimitrij, Fibichovy Námluvy Pelopovy a dvě činohry (Služebník svého pána od Františka Věnceslava Jeřábka a Jan Výrava od F. A. Šuberta).

40 REITTEREROVÁ, Vlasta - REITTERER, Hubert. Slovanský element a vídeňské (hudební) divadlo. In Slovanství a česká kultura v 19. století. „Slavme slavně slávu Slávóv slavných“. Praha: KLP, 2006, s. 294.

41 Úspěch Prodané nevěsty ve Vídni se odehrával v době zvýšeného napětí při sporu o takzvané punktace, které měly nově vymezovat vztah Čechů a Němců v českých zemích, proto byl sledován se zvýšenou pozorností i v nehudebním tisku. In ŠUBERT, František Adolf. České Národni divadlo na prvni mezinárodni divadelni výstavě ve Vidni r. 1892. Sepsal a sestavil Fr. A. Šubert, Praha 1892, s. 187. 
úspěchu zanechal ve svých pamětech, publikovaných ve třicátých letech minulého století, dramatik a režisér Jaroslav Kvapil, jenž se zúčastnil zájezdu jako zvláštní dopisovatel. „Dobyli jsme Vídně víc než tenkrát kdejaká politika... A necht’ byla Videñ jaktěživa národně i politicky sebenevlidnějši: ,Prodané nevěstě a české hudbě se krásně odvděčila. Stala se naši výpadni bránou do ciziny. Dnes to vypadá jako samozřejmost, tenkráte to byla závratná radost, opojeni, nová vzpruha pro budoucnost. " ${ }^{2}$ Tento vídeňský triumf přinesl Smetanovým operám první velké mezinárodní uznání ${ }^{43}$ a představoval také nový silný impuls pro domácí hudební kruhy, a to nejen v oblasti interpretační či provozovací praxe, nebot ovlivnil ve vlastní zemi i důvěru v české operní umění vůbec. V roce 1893 tvořila česká díla v Národním divadle dokonce polovinu divadelního repertoáru. O definitivním prosazení Smetanova díla vypovídá také skutečnost, že v září 1893 se v Národním divadle uskutečnil první cyklus Smetanových oper, díky němuž se všechny dostaly na repertoár divadla, i když ještě ne natrvalo.

Výše pojednané boje o Smetanu ze sedmdesátých let 19. století, které po Smetanově smrti utichly, se znovu vrátily počátkem 20. století. Jejich charakter se ve srovnání s první etapou proměnil a zasáhl také tvorbu Antonína Dvořáka. Zapojil se do nich i skladatel a ideový kritik Otakara Hostinského Ludvík Lošták. ${ }^{44}$ Hostinskému vytýkal, že ideál hudebního dramatu se mu stal „estetickým kopytem, na něž narážel pak každou dramatickou práci Smetanovu. "45 Dále poukazoval na Hostinského názorovou dvoukolejnost, oddělování skladeb rázu národního a rázu moderního, kterou poměřoval Smetanovou tvorbu. Výsledkem této dichotomie byla podle Loštáka Hostinského neschopnost vidět a slyšet ve Smetanově hudbě vlastní originální styl. „Sloh, pane profesore, jest oduševnělá tvář umělcova! Sloh je nos, oči, brada, ústa, zuby, čelo, uši a vlasy umělcovy, a proto ono nekonečné škatulkováni dvou slohi̊, dvou tvář́ uměleckých jest tou nejprotivnějši vlastností starosvětské kritiky šosácké, uboze netvořivé a neplodně scurklé!" “46 Do smetanovské recepce výrazně zasáhl Zdeněk Nejedlý, jehož propojení umění, vědy a politiky významně poznamenalo českou kulturu. Navázal na Hostinského stanoviska a koncepci Smetanova významu pro moderní českou hudbu. Př́stup Nejedlého ke Smetanovým operám se odvíjel na základě mnohostranného rozboru, tedy na vylíčení dramatického charakteru každé zpěvohry v souvislosti

42 KVAPIL, Jaroslav. O čem vím. II. část. Praha: Jos. R. Vilímek, 1947, s. 152.

43 Po vídeňském vystoupení začal Smetanovy opery nabízet vídeňský nakladatel Josef Weinberger Dvorní opeře, a sice Branibory v Čechách, Dalibora, Hubičku, Tajemství, Libuši a Dvě vdovy. V následujícím roce byla Prodaná nevěsta uvedena v Divadle na Vídeňce v německém překladu Maxe Kalbecka. Teprve o tři roky později r. 1896 se uskutečnilo první provedení ve vídeňské Dvorní opeře. Tato první inscenace se hrála do roku 1918 a počtem 99 repríz zůstala dodnes nejúspěšnější z celkem 9 inscenací této opery v operním domě na Okružní třídě, dnes Vídeňské státní opeře (viz REITTEREROVÁ, Vlasta. Dvě první vídeňské Prodané nevěsty a jejich představitelé / Theater an der Wien 1893, Hofoper 1896/. Musicalia, 2016, č. 1-2, s. 22-36). Během devadesátých let 20. století byla Prodaná nevěsta uvedena v mnoha evropských městech, zejména v německy mluvícím prostoru, a nepřestala se rozšiřovat ani na počátku 20. století, kdy se postupně prosadila i na ostatních kontinentech.

44 LOŠŤÁK, Ludvík. Chromatické hromobití. Praha: Nákladem vlastním, [1900].

45 LOŠŤÁK, [1900], op. cit., s. 12.

46 LOŠŤÁK, [1900], op. cit., s. 22-23. 
s historicko-kulturním pozadím a lidskou stránkou originální osobnosti skladatele. ${ }^{47} \mathrm{Ne}$ jedlého vztah ke Smetanovu dílu byl však zatížen neustálým vyzdvihováním Smetany jako jediného zakladatelského a pokrokového vzoru. To vedlo k hodnocení Smetanovy hudby jako vyšší než Dvořákovy a k permanentnímu konfrontačnímu tónu směrem ke konzervativnímu a nepokrokovému Dvořákovi. ${ }^{48}$ Nejedlý sice ve svých názorech vychází z Hostinského, ovšem výrazným zpo̊sobem je vyhrocuje. Dělo se tak i v dalších Nejedlého pracích dotýkajících se tématu Smetanových oper a jejich recepce. ${ }^{49}$

V roce 1910 Nejedlý založil časopis Smetana ${ }^{50}$ a Hudební klub ${ }^{51}$, které měly posílit Nejedlého pozice ve smetanovských bojích s kruhy soustředěnými kolem časopisů Dalibor ${ }^{52}$ a Hudební revue ${ }^{53}$. Bylo to v situaci, kdy se na přelomu prvního a druhého desetiletí 20. století nové smetanovské boje znovu ostře vyhrotily a přerůstaly ve spory kulturně-politické, v nichž se srážely dvě koncepce pojetí minulosti a přítomnosti českého hudebního života. Klíčovou úlohu sehrála přednáška Karla Steckera ${ }^{54}$ a na ni navazující polemika Helfert-Stecker v časopisech Smetana a Hudební revue. Vladimír Helfert přednášku považoval za Steckerovu snahu doložit, jak Hostinský nepochopil, oč Smetana usiloval, a jak naopak Smetana nedokázal vzdorovat Hostinského zaujetí pro Wagnerovu operní reformu. Helfert polemiku postavil na vysvětlení a významovém rozlišení pojmů wagnerianismus, tj. Wagnerova vlastního estetického názoru, a wagnerismus, tj. převtělení tohoto estetického názoru do konkrétního díla. ${ }^{55}$ Po Helfertově reakci Stecker publikoval svou odpověd', v níž tvrdil, že si Smetana našel vlastní cestu syntézou dvou stylů, tj. zpěvnosti a deklamatorního stylu. ${ }^{56}$ Podle něj tedy Hostinského snaha, kterou se snažil Smetanu nasměrovat, nebyla úspěšná. Stecker stavěl smetanismus do protikladu k wagnerianismu

47 NEJEDLÝ, Zdeněk. Zpěvohry Smetanovy. Praha: J. Otto, 1908. Z literatury o Smetanových zpěvohrách byla pro Nejedlého nejlepším vystižením Smetanova slohového vývoje Hostinského stat $O$ zpěvohrách Smetanových (HOSTINSKÝ 1941, op. cit., s. [377]-439).

48 Nejedlého koncepce se zakládala na ideji dvou linií vývoje moderní české hudby, rozvíjejících se paralelně od sedmdesátých let 19. století, jedné pokrokové, druhé zpátečnické. Tato dichotomie byla patrně do značné míry odrazem dichotomie Wagner-Brahms v dobovém (zejména německojazyčném) diskursu o hudbě.

49 Např. NEJEDLÝ, Zdeněk. Opera Národního divadla od roku 1900 do převratu. Praha: Sbor pro zř́zení druhého Národního divadla v Praze, 1936.

50 První pokus o založení časopisu Smetana učinil Jan Branberger, vycházel pouze rok (1906-7). U zrodu časopisu v roce 1910 stál Zdeněk Nejedlý, redigoval jej Artuš Rektorys.

51 O úloze a historii tohoto spolku pojednává studie Hudební klub v Praze (1911-1927). In ČORNEJ, Petr. Historici, historiografie a dějepis. Karolinum, 2016.

52 Dalibor byl znovu obnoven roku 1879, vycházel do r. 1913 a potom ještě v letech 1919-1927, red. Václav J. Novotný.

53 Hudební revue vycházelo v letech 1908-1920, nástupcem se v roce 1921 staly Listy hudební matice (od r. 1927 Tempo).

54 Přednesena byla na slavnostním shromáždění České akademie roku 1910, vydána o dva roky později viz STECKER, Karel. Otakar Hostinský a jeho význam pro tvorbu Bedřicha Smetany. Praha: Fr. A. Urbánek, 1912.

55 HELFERT, Vladimír. Smetanismus a Wagnerianismus. Smetana, 1911, roč. 1, č. 11, s. 168. Vycházelo na pokračování v č. 11-13, s. 167-173, 188-197. Více k tématu viz OTTLOVÁ, Marta - POSPÍŠIL, Milan. K motivům českého wagnerismu a wagnerianismu. In Bedřich Smetana a jeho doba. Vybrané studie. Praha: Nakladatelství Lidové noviny, 1997, s. 96-110.

56 STECKER, Karel. K otázce Smetanismu a Wagnerianismu. Praha: Nákladem vlastním, 1911. 
- jeho znaky spatřoval ve Smetanově zpěvnosti či v pozůstatcích předwagnerovské opery (hlavně ve Dvou vdovách, Tajemstvi a Čertově stěně) a většinu Smetanových oper pokládal především za hudbu, nikoli za drama. Helfert naproti tomu Smetanu považoval za vědomého stoupence deklamatorního stylu i hudebního dramatu a smetanismus chápal jako tvůrčí aplikaci Wagnerových principů.

Ke strážcům smetanovské tradice patřili také F. X. Šalda a Ferdinand Pujman. Šalda si Hostinského názorů vážil, měl však výhrady k jeho pojednání otázky vztahu Smetany k Wagnerovi. „Proni badatelé smetanovští, zvláště zvěčnělý Hostinský, hájili a pojímali českého tvưrce sub specie Richarda Wagnera. Viděli v něm zjev uměleckého pokroku, jak se vyjadřovali, zjev obdobný tvůrci dramatu hudebního, který vyléčil jako Wagner starou operu ze strakatých pošetilosti a naivního dětského nedomyšleni. " ${ }^{\text {57 }}$ Podle Šaldy Hostinský nerozlišil, do jaké míry se Smetana od Wagnera odlišoval. V každém ze skladatelo̊ viděl génia jiného druhu. Uvítal tudíž, když k podobným závěrům dospěl režisér Smetanových oper Ferdinand Pujman. Ten byl přesvědčen o Smetanově úplné umělecké nezávislosti na Wagnerovi a o jeho samostatném místě mezi nejpřednějšími světovými génii. ${ }^{58}$ Šalda pozitivně hodnotil hlavně to, že Smetana byl pro Pujmana „nejčistší Wagnerův protinožec“ a že se mu poprvé podařilo určit „Smetanův tvůrčí typ“. „Mezi Smetanou a Wagnerem jsou sice jisté analogie (nic vic), které vyplynuly z reformátorského postoje jich obou $k$ domácím šosákům a pedantům, ale jinak je Smetana svou podstatou, jádrem svého uměni zjev zcela samostatný, který se od Wagnera diametrálně liší, ba který je v mnoha závazných bodech přimo Wagnerův antipod. [...] Smetana je zcela jinýv methodě svého umění, v prvcich a struktuře svého dila. Je zcela jiný temperament, zcela jiný psychologický charakter, zcela jiný rodem své duše a svého génia. Jeho umění je ve svých prvcich ryze české, má svou mizu z morku lidu. "59

Koncem 19. století vrcholil prohlubující se zájem o historii a o formování národní identity. Vztah české hudební veřejnosti ke Smetanovu odkazu sílil, blížilo se první kulaté smetanovské výročí a na podzim roku 1893 vzešel od tehdejšího ředitele Národního divadla Šuberta při valné hromadě Družstva Národního divadla návrh na zřízení instituce, jež by shromažd’ovala památky dokumentující osobnost, život a dílo Bedřicha Smetany. ${ }^{60}$ Důležitým hybatelem těchto snah byl Sbor pro postavení Smetanova pomníku v Praze ${ }^{61}$ který byl založen v roce dvacátého pátého výročí Smetanova úmrtí, roku 1909. Původní záměr spolku - zbudování Smetanova pomníku - byl záhy překonán a Sbor se postupně stal institucionálním tvưrcem a nositelem smetanovského programu. Čtvrtstoletí po Smetanově smrti se projevil zvýšený zájem o skladatelův odkaz jak na poli hudební

57 ŠALDA, František Xaver. Poznávání Smetany. Venkov, 20. 1. 1918, roč., 13, č. 18, s. 3.

58 PUJMAN, František. Smetanovský brevirr. Praha: Fr. Borový, 1917.

59 Cit. dle ŠALDA, František Xaver. Mladá hudební generace v Čechách. In Kritické projezy 3. Praha: Melantrich, 1950, s. 231-232. Stat’ původně vyšla In Die Zeit. Wiener Wochenschrift für Politik, Volkswirtschaft, Wissenschaft und Kunst, 6. 3. 1897, Bd. 10, Nr. 127, s. 154-156.

60 První podnět k založení Smetanova muzea byl zveřejněn již v r. 1889, viz HEJDA, František Karel. Slavná redakce „Dalibora“! Dalibor, 1889, roč. 11, č. 4, s. 30-31.

61 Od roku 1931 Společnost Bedřicha Smetany. Viz ČECHOVÁ, Olga. K historii Společnosti Bedřicha Smetany. In KUNA 1985, op. cit, s. 207-216. 
vědy a divadelní či koncertní praxe, tak ve společenském rozměru - konaly se různé pietní a vzpomínkové akce, mj. se objevily také úvahy o vzniku Smetanova festivalu. ${ }^{62}$

Počátkem 20. století se Národní divadlo vydalo pod novým vedením na novou cestu. S nástupem Karla Kovařovice do vedení opery v roce 1900 začala nová etapa v provozování Smetanova díla zejména směrem k respektování původní (Smetanou definované) podoby jednotlivých děl. ${ }^{63}$ Všechny Smetanovy opery se až tehdy staly trvalou součástí repertoáru a v jejich inscenování se začal prosazovat nový přístup - započalo „léčeni kardinálních nedostatků naši opery $i$ vad, které činily poslechnuti mnohého díla často skutečně nemožným “. ${ }^{64} \mathrm{~V}$ prvních čtyřech letech Kovařovic uvedl v novém nastudování všech osm Smetanových oper, k čemuž ředitel Gustav Schmoranz konstatoval, že k tomu „dřivějši správa potřebovala 6 let a 7 měsiců, tedy dobu málem dvojnásobnou než správa nynější. "65 Tajemstvi se stalo repertoárovým, ale i kasovním kusem. Čertova stěna a Braniboři v Čechách se často uváděly i mimo cyklus. Dvě vdovy se postupně přibližovaly k podobě Smetanovy druhé verze opery z roku 1877 a Dalibor se oproti předcházející praxi provozoval nezkrácený ${ }^{66}$

V okamžiku, kdy do evropského vývoje zasáhla první světová válka a její průběh dal českému národu naděje na politické osamostatnění, nabýval Smetanův odkaz na aktuálnosti. Smetanova hudba posilovala české národní vědomí a stávala se znovu přitažlivou a mobilizující. Atmosféru v kulturní společnosti vystihla následující slova Vladimíra Helferta: „Nuže, náš hudebni život vykoná svưj nejvlastnějši kulturni úkol v dnešni naši situaci, bude-li co nejdi̊razněji udržovat při životě českou moderni hudbu se Smetanou v čele. "67 Ve válečných letech 1914-1918 podněcovala Prodaná nevěsta k národním manifestacím, které měly pro obyvatele posilující význam, např. při oslavách padesátého výročí jejího prvního uvedení. Před začátkem byl sehrán výjev Hold Prodané nevěstě, režírovaný Schmoranzem, „v němž vřelými slovy pověděli představitelé všech vrstev českého národa, čím naše jubilantka, jeji hudba národu byla a jest [...]. Nesmrtelná, po všem světě slavená opera Smetanova, vstupuje

62 Srov. HELFERT, Vladimír. K letošním Smetanovým oslavám, Pražská lidová revue, 1909, roč. 5, č. 5. s. 137-139.

$63 \mathrm{~K}$ nejdiskutovanějším tématům patřila otázka relevance úprav Smetanových oper. Kritika se zabývala otázkou, do jaké míry je či není vưči skladatelově památce prohřeškem, dostane-li se jeho dílu úpravy, která ho může, ale i nemusí zbavit živoření na jevišti a znovu uvést v divadelní život. Životnost či neživotnost Smetanových oper se mnohdy odvíjela od kvalit libreta. Proto když pokusy o rehabilitaci tzv. nepopulárních oper selhávaly a jejich návštěvnost zásadně nerostla, vznikla idea úpravy textů, kdy mělo být „vymýceno vše kostrbaté“. Úprav se dočkaly tři Smetanovy opery - Dalibor (1886), Dvě vdovy (1893) a Braniboři v Čechách (1903). Jejich upravovatelem byl Václav Juda Novotný. „Sblížení mezi dílem a obecenstvem“ ovšem ani tyto úpravy nedocílily. To vedlo k přesvědčení navrátit se od zkreslujících úprav k původním zněním. Kovařovicovy návraty však nebyly ještě zcela důsledné. Jako rozený kapelník, měl sklony ke škrtům, změnám instrumentace a úpravy děl toleroval. K důsledným návratům dospěl až ve dvacátých letech 20. století Kovařovicův nástupce Otakar Ostrčil, jehož zásadou bylo uvádět díla mistrů dle původní partitury. Teprve za jeho éry slyšeli diváci Smetanovy opery v autentickém znění.

64 HOFFMEISTER, Karel. Smetanův „Dalibor“. Dalibor, 1900, roč. 22, č. 28, s. 221.

65 SCHMORANZ, Gustav. Dvacátý rok Národního divadla 1902-1903. Praha: Nakladatelství Národního divadla, 1903, s. 34 .

66 MINDL, Josef. Opera Národního divadla v minulosti a budoucnosti. Hudebni revue, 1911, roč. 4, č. 10, s. 529-533.

67 HELFERT, Vladimír. Náš hudební život ve válce. Úkol našeho umění a zejména hudby. Národní divadlo. Česká operní tvorba a Národní divadlo. Naše doba, 1915, roč. 22, č. 3, s. 268-271. Cit. dle HELFERT, Vladimír (Štědroň, Bohumír ed.). O Smetanovi (Soubor stati a článků). Praha: Hudební Matice, 1950, s. 72. 
do druhého prilstoletí svého života. Necht' $i$ v něm kráči vítězně světem $k$ slávě svého tvưrce $i$ našeho národa! “68 Tato společensko-politická situace příznivě ovlivnila uspořádání rozsáhlé Smetanovy výstavy v roce 1917. Na výstavě se podařilo shromáždit množství originálních smetanovských pramenů, dokumentujících nejen skladatelův život a tvorbu, ale i jeho dobu a další osudy jeho děl. ${ }^{69} \mathrm{Na}$ výzvu pro získání Smetanových památek zareagovala jak skladatelova rodina, tak i široká veřejnost, a nashromážděný materiál, který vytvořil základ pro sbírky, myšlenku vzniku muzea jako „živého pomníku“, sloužícího dalšímu pěstování Smetanova díla a šíření znalostí o jeho osobě, tvorbě i době, tak výrazně podpořil. ${ }^{70}$, „[...] na každého učini výstava nutně hluboký dojem překvapujicí novosti právě svou životnosti, t $j$. tím, že vyvolává v návštěvniku zcela konkrétni, živý obraz Smetanova života a všeho, co se $k$ němu družilo. To pak povyšuje výstavu na zcela mimořádný zjev; sem nechodi se pro zvědavost, proto, že by bylo zde možno něco ,zajimavého' spatřit; kdo sem jde, pricházi uctivat Smetanovo dílo a jeho život, přicházi poklonit se jeho snahám a jeho utrpeni. Z této Smetanovy výstavy tvoři se skutečná svatyně národniho umělce. "71

Úsilí o státní samostatnost bylo završeno v roce 1918 vznikem Československé republiky a Smetanovo dílo bylo obecně respektováno jako nepostradatelná součást národní kultury. Publikum si doslova vynucovalo nová provozování českého repertoáru. V první den svobody již vedení divadla nestačilo provést změnu představení, a tak se podle plánu odehrála Carmen, ale první dny existence samostatného státu přirozeně provázela hudba Bedřicha Smetany. Při slavnostním představení Prodané nevěsty 29. října 1918 v Národním divadle bylo na ceduli uvedeno „v první den svobody“. „Večer Kovařovic $s$ orchestrem překonávali sama sebe. Nadšeni neobvyklé propuklo hned po ouvertuře s takovou elementárni silou, že mráz nás přešel. Vyhrnula se opona a scéna zářila v kalvodovské výpravě mimořádným kouzlem a jasem. Ze všech koutů sálalo cosi tak neobvykle hřejivého a tak neobvykle š́astného. Byl to náš český obrázek, náš český život v prvý den svobody!"72 Dalších sedm dní byly na programu divadla (někdy i dvakrát denně) pouze české tituly. Prvního listopadu večer se konalo slavnostní představení opery Libuše v titulní roli s Emou Destinnovou. Smetanova hudba se ujímala nových rolí, například slavnostní fanfáry z Libuše se staly hudebním symbolem hlavy československého státu nebo harfový motiv Vyšehradu znělkou nově vzniklého pražského rozhlasu.

Od otevření Národního divadla do konce 19. století poměr uvádění českých oper postupně narůstal, a to z méně než čtvrtiny na téměř polovinu. ${ }^{73}$ Tato hodnota se v prvním

68 [?] Oslava 50. výročí prvního provozování „Prodané nevěsty“. Národni listy, 31. 5. 1916, roč. 56, č. 150, s. 3.

69 Iniciátorem akce byl Klub pensionovaných sólistů Národního divadla. Výstava se konala v Národopisném muzeu v zahradě Kinských. Hlavním autorem výstavy byl Zdeněk Nejedlý, spolupracovali sochař Jindřich Čapek, Karel Guth a František Kysela.

70 Podrobný soupis exponátů viz Nejedlý, Zdeněk. Katalog Smetanovy výstavy v Praze 1917. [Praha]: nákladem Smetanovy výstavy, [1917].

71 HELFERT, Vladimír. Smetanova výstava. Smetana, 1917, roč. 7, č. 8-9, s. 115.

72 HUML, Jiří. In Almanach na památku tisícího provedeni Prodané nevěsty souborem Národního divadla v Praze 30. května. Praha: Národní divadlo, 1927, s. 77.

73 Uvedený nárůst, patrný zejména v druhé půli Šubertova období, vysvětluje vlastenecké nadšení vyvolané konáním několika výstav (zmíněná Mezinárodní hudební a divadelní výstava ve Vídni nebo Národopisná výstava českoslovanská v roce 1895 v Praze). 
desetiletí 20. století nezměnila, avšak v druhé půli období šéfování Karla Kovařovice (1912-1920) se zvedla téměř na 54\%. V té době bylo z patnácti nejčastěji provozovaných oper v Národním divadle deset českých, z toho šest oper B. Smetany - Prodaná nevěsta, Dalibor, Hubička, Libuše, Tajemstvi a Dvě vdovy. ${ }^{74}$ Uvedený vyšší poměr provozování českých oper souvisel se vzrušením vyvolaným vznikem československého státu na konci 1. světové války. V období vzniku samostatného československého státu význam a role Smetanova odkazu rostly, a tak v roce 1919 rozširril Sbor pro postavení Smetanova pomníku svůj program o souborné vydání Smetanova díla, korespondence a deníků75 a oživil myšlenku zřízení monografického muzea jako centra smetanovského bádání i propagace jeho idejí, v té době zcela ojedinělou. ${ }^{76}$ Po smrti Karla Kovařovice se v prosinci 1920 po svém ročním působení ve funkci dramaturga stal šéfem opery Národní divadla Otakar Ostrčil. V duchu Smetanových slov, že „pěstováni domácího umění je pruni a nejkrásnějši úloha naši opery “,77 kladl stejně jako Kovařovic důraz na českou operní tvorbu zahrnující jak klasická díla, tak soudobou produkci. Po celý svůj profesní život Ostrčil hledal nejautentičtější možný způsob interpretace. Za svůj hlavní cíl si vytkl zbavení Smetanových oper všeho upravovatelského nánosu.

Role Smetanovy hudby jako reprezentanta národa, ale i nového československého státu vyvrcholila v roce 1924. Oslavy stého výročí Smetanova narození se tehdy staly jeho vrcholnou a reprezentační kulturní událostí. ${ }^{78}$ Organizaci oslav řídil Sbor pro postavení Smetanova pomníku. Jeho původní záměr - realizace pomníku - paradoxně nebyl ani u př́ležitosti jubilejního roku uskutečněn. Činnost Sboru byla během oslav široká. Dohlížel na odhalení pamětních desek či pomníků, at již přímo v Praze nebo na jiných místech republiky, spojených se životem a dílem hudebního skladatele. Podílel se také na pořádání osvětových přednášek, prezentacích v tisku a v tomto směru především na vydání slavnostních publikací, vztahujících se ke Smetanovu životu i tvorbě, včetně edice jeho díla. Jeho předsedou byl spisovatel František Táborský, místopředsedy Zdeněk Nejedlý a Josef Jiránek, jednateli Karel Guth a Josef Bartoš. ${ }^{79}$ Oslavy byly projevem úcty národa

74 VIKTOROVÁ, Kateřina. Recepce Smetanových oper v éře Karla Kovařovice. Opus musicum, 2018, roč. 50, č. 6 , s. 6-37.

75 Viz MOJŽÍŠOVÁ, Olga. Smetanovský dluh české muzikologie - písemné prameny jako předmět zájmu smetanovského bádání. Musicologica Brunensia, 2015, roč. 50, č. 1, s. 153-164.

76 K založení Smetanova muzea nakonec došlo v roce 1926. Správou sbírek byl pověřen Zdeněk Nejedlý. O dva roky později se zasloužil o zakoupení Smetanovy pozůstalosti od jeho dědiců, která byla do muzea předána v letech 1929-1932. Ǩadu památek si rodina nadále ponechala. Podrobný soupis převzatých materiálů viz WAISAR, Alfons. Soupis pozůstalosti Bedřicha Smetany. In Zprávy Společnosti Bedřicha Smetany 1, Praha: nákladem Společnosti Bedřicha Smetany, 1931-1932, s. 38-52. Muzeum v té době nemělo vhodný objekt ke své činnosti. Sbírkové předměty v majetku muzea byly prozatímně uloženy a postupně zpracovávány v Ústavu pro hudební vědu Karlovy univerzity. Až v roce 1935 se Společnosti Bedřicha Smetany podařilo propůjčit si od pražské obce budovu Staroměstské vodárny, v níž sídlí dodnes. 12. května 1936 bylo muzeum za účasti tehdejšího československého prezidenta Edvarda Beneše slavnostně otevřeno.

77 [SMETANA, Bedřich]. Veřejný život hudební v Praze. I. Opera. Národni listy, 15. 7. 1864, roč. 4, č. 190, s. 1.

78 Více o programu viz Program jubilejních slavností Bedřicha Smetany. Smetana, 1923, roč. 13, č. 7-8, s. 97-99.

79 Paralelně s pražským Sborem existoval v Brně Sbor pro oslavu stých narozenin Bedřicha Smetany na Mo- 
ke svému géniu a souvisely i s vlastenectvím počátečního období první republiky. Jubileum se nepřehlédnutelně zapsalo do celorepublikového kulturního dění, nebot oslavné akce zasahovaly do všech oborů umění, od Prahy po vesnici, od vrcholných profesionálních produkcí po amatérskou sféru, a byly završením dosavadního celonárodního uznání Smetanovu odkazu. ${ }^{80}$ Největší pozornost se upínala k jádru oslav - slavnostnímu cyklu v Národním divadle, v němž zazněly všechny Smetanovy opery. Součástí oslav byl také cyklus pěti koncertů prezentující Smetanovu tvorbu s výjimkou klavírního díla v podstatě v úplnosti. Uspořádána byla i další velká výstava v prostorách Uměleckoprůmyslového muzea, v jejímž rámci byl vystaven ještě rozsáhlejší soubor památek než v roce $1917 .{ }^{81}$ Odhalovány byly pamětní desky i pomníky, at již přímo v Praze, nebo na dalších místech země spojených se skladatelovým životem. Oslavy měly i mezinárodní dimenzi - v Praze se konal Mezinárodní hudební festival, jehož pořadatelem byla československá sekce Mezinárodní společnosti pro soudobou hudbu. ${ }^{82}$ Jubilejní oslavy roku 1924 zasáhly široké vrstvy obyvatelstva, a proto měly značný podíl mj. na dobré znalosti (aktivní i pasivní) Smetanovy tvorby. Ve společnosti panovala velká chut’ pěstovat Smetanovu hudbu - hrát Smetanu se stalo otázkou národní a profesní prestiže. Smetanovské oslavy roku 1924 jsou dodnes považovány za absolutní vrchol dosavadních smetanovských aktivit, který nebyl intenzitou ani kvalitou dosud překonán.

\section{Bibliography}

BARTOŠ, Josef. Mezinárodní hudební festival v Praze 1924. Smetana, 1924, roč, 14, č. 5-6, s. 65-73. BERKOVEC, Jiří - JIRÁNEK, Jaroslav - SMOLKA, Jaroslav. Reflexe Smetanova díla a odkazu. In KUNA, Milan (ed.). Sto let odkazu Bedřicha Smetany. Př́spěvky a studie z konference hudebně vědecké oblasti Svazu českých skladateli̊ a koncertnich umèlců v Praze. Praha: Svaz českých skladatelů a koncertních umělců, 1985, s. 93-104.

BRÁFOVÁ, Libuše. Rieger, Smetana, Dvořák. Praha: Fr. A. Urbánek, 1913.

ČECHOVÁ, Olga. K historii Společnosti Bedřicha Smetany. In KUNA, Milan (ed.). Sto let odkazu Bedřicha Smetany. Př́spě̀ny a studie z konference hudebně vědecké oblasti Svazu českých skladatelĩ a koncertnich umělcư v Praze. Praha: Svaz českých skladatelů a koncertních umělců, 1985, s. 207-216.

ČORNEJ, Petr. Historici, historiografie a dějepis. Karolinum, 2016.

FUKAČ, Jiří - PAVLÍČKOVÁ, Jana. Sémantická otevřenost jako faktor recepce Smetanova díla. In KUNA, Milan (ed.). Sto let odkazu Bedřicha Smetany. Př́spěvky a studie z konference hudebně vědecké

ravě a ve Slezsku a v Bratislavě Sbor pre usporiadanie oslav B. Smetanovi na Slovensku. Sbory zajištovaly oslavné podniky v místě svého působiště. Podrobně k průběhu oslav viz PALA, František. Opera Národního divadla v obdobi Otakara Ostrčila, II. díl. Praha: Divadelní ústav, 1964, s. 270-274, s. 297-309.

80 MOJŽÍŠOVÁ 2012, op. cit., s. 41.

81 NEJEDLÝ, Zdeněk. Seznam památek ze života a díla Bedřicha Smetany vystavených na Smetanově výstavě pořádané Sborem pro postaveni pomniku Bedřichu Smetanovi v Praze v jubilejním roce 1924 v sinich Umělecko-průmyslového musea v Praze. Praha: Sbor pro postavení pomníku Bedřichu Smetanovi v Praze, [1924].

82 Srov. Mezinárodní hudební festival 1924. Listy Hudebni Matice, 1924, roč. 3, č. 8, s. 300-301. Dále také BARTOŠ, Josef. Mezinárodní hudební festival v Praze 1924. Smetana, 1924, roč, 14, č. 5-6, s. 65-73. 
oblasti Svazu českých skladateli̊ a koncertnich umělců v Praze. Praha: Svaz českých skladatelů a koncertních umělců, 1985, s. 133-146.

HEJDA, František Karel. Slavná redakce „Dalibora“! Dalibor, 1889, roč. 11, č. 4, s. 30-31.

HELFERT, Vladimír. K letošním Smetanovým oslavám, Pražská lidová revue, 1909, roč. 5, č. 5. s. 137-139.

HELFERT, Vladimír. Smetanismus a Wagnerianismus. Smetana, 1911, roč. 1, č. 11.

HELFERT, Vladimír. Náš hudební život ve válce. Úkol našeho umění a zejména hudby. Národní divadlo. Česká operní tvorba a Národní divadlo. Naše doba, 1915, roč. 22, č. 3, s. 268-271.

HELFERT, Vladimír. Smetanova výstava. Smetana, 1917, roč. 7, č. 8-9, s. 113-115.

HELFERT, Vladimír (Štědroň, Bohumír ed.). O Smetanovi (Soubor stati a článků). Praha: Hudební Matice, 1950.

HELFERT, Vladimír. Cesty za novým stylem. Otázka Smetanovy tradice. In Vybrané studie I. O hudebni tvořivosti. Praha: Editio Supraphon, 1970.

HNILIČKA, Alois. B. Smetana a spory v letech sedmdesátých o češství děl jeho. In Rozhledy po životě a významu Bedřicha Smetany, Praha: Mojmír Urbánek, 1924, s. 107-120.

HOFFMEISTER, Karel. Smetanův „Dalibor“. Dalibor, 1900, roč. 22, č. 28, s. 221-222.

HOLUBOVÁ, Eliška. Smetanismus. In FUKAČ, Jiří - VYSLOUŽIL, Jiří (red.). Slovnik české hudebni kultury. Praha: Editio Supraphon, 1997.

[HOSTINSKÝ, Otakar] Smetanovy dopisy. Dalibor, 1885, roč. 7, č. 18-19, s. 173-175.

HOSTINSKÝ, Otakar. Česká hudba 1864-1904, Praha 1909.

HOSTINSKÝ, Otakar. Bedřich Smetana a jeho boj o moderni českou hudbu. Vzpominky a úvahy. Praha: Jan Laichter, ${ }^{1} 1901,{ }^{2} 1941$, s. 233-268.

HOSTINSKÝ, Otakar. O zpěvohrách Smetanových. In HOSTINSKÝ, Otakar. Bedřich Smetana a jeho boj o moderni českou hudbu. Vzpominky a úvahy. Praha: Jan Laichter, 1941, s. [377]-439.

HOSTINSKÝ, Otakar. Zevnější úspěchy zpěvoher Smetanových. In HOSTINSKÝ, Otakar. Bedrich Smetana a jeho boj o moderni českou hudbu. Vzpominky a úvahy. Praha: Jan Laichter, 1941, s. $440-449$.

HUML, Jiří. In Almanach na památku tisíciho provedeni Prodané nevěsty souborem Národního divadla v Praze 30. května. Praha: Národní divadlo, 1927.

CHVÁLA, Emanuel. Otevření Národního divadla. Dalibor, 1881, roč. 3, č. 18, s. [139]-141.

KADLEC, Petr. Pražská recepce Smetanových oper 1884-1900. Univerzita Karlova. Filozofická fakulta, 2006. Magisterská diplomová práce.

KREJČÍ, František Václav. Bedřich Smetana. Praha: Pelcl, 1900.

KVAPIL, Jaroslav. O čem vím. II. část. Praha: Jos. R. Vilímek, 1947.

LOŠŤÁK, Ludvík. Chromatické hromobití. Praha: Nákladem vlastním, [1900].

LÖWENBACH, Jan. První apoštol hudby Smetanovy, Hudebni revue, 1908, roč. 1, č. 7, s. [329]-351.

MINDL, Josef. Opera Národního divadla v minulosti a budoucnosti. Hudebni revue, 1911, roč. 4, č. 10, s. 529-533.

MOJŽÍŠOVÁ, Olga. Odkaz Bedřicha Smetany - vývoj a proměny jeho recepce. In Národní identita/y. Praha: Institut umění - Divadelní ústav - Česká hudební rada, 2012, s. 39-45.

MOJŽÍŠOVÁ, Olga. Smetanovský dluh české muzikologie - písemné prameny jako předmět zájmu smetanovského bádání. Musicologica Brunensia, 2015, roč. 50, č. 1, s. 153-164.

NEJEDLÝ, Zdeněk. Zpěvohry Smetanovy. Praha: J. Otto, 1908.

NEJEDLÝ, Zdeněk. Bedřich Smetana a kulturni politika F. L. Riegra, Praha: Melantrich, 1915.

NEJEDLÝ, Zdeněk. Katalog Smetanovy výstavy v Praze 1917. [Praha]: nákladem Smetanovy výstavy, [1917].

NEJEDLÝ, Zdeněk. Seznam památek ze života a dila Bedřicha Smetany vystavených na Smetanově výstavě pořádané Sborem pro postaveni pomniku Bedřichu Smetanovi v Praze v jubilejním roce 1924 v sinich 
Umělecko-priomyslového musea v Praze. Praha: Sbor pro postavení pomníku Bedřichu Smetanovi v Praze, [1924].

NEJEDLÝ, Zdeněk. Opera Národniho divadla od roku 1900 do převratu. Praha: Sbor pro zřízení druhého Národního divadla v Praze, 1936.

[NERUDA, Jan]. Feuilleton. Národni listy, 28. 2. 1875, roč. 15, č. 58, s [2].

OTTLOVÁ, Marta - POSPÍŠIL, Milan. K motivưm českého wagnerismu a wagnerianismu. In $B e-$ dřich Smetana a jeho doba. Vybrané studie. Praha: Nakladatelství Lidové noviny, 1997, s. 96-110.

PACLT, Jaromír. Vídeň 1892 - most do světa. Divadelni revue, 1994, č. 2, s. 35.

PALA, František. Opera Národního divadla v obdobi Otakara Ostrčila, II. dil. Praha: Divadelní ústav, 1964, s. 270-274, s. 297-309.

PECHAC̆, Marek. Reflexe dila Richarda Wagnera v osmdesátých letech 19. století v českých zemích. FF UP, Olomouc 2011. Diplomová práce.

PIVODA, František. Hovorna. Panu Bedřichu Smetanovi, prvnímu kapelníku české opery. Pokrok, 3. 3. 1870 , roč. 2 , č. 61 , s. 3 .

P. [PROCHÁZKA, Ludevít]. Dalibor. Národni listy. 18. 5. 1868, č. 137, roč. 8, s. 3.

PUJMAN, František. Smetanovský breviřr. Praha: Fr. Borový, 1917.

REITTEREROVÁ, Vlasta - REITTERER, Hubert. Slovanský element a vídeňské (hudební) divadlo. In Slovanstvi a česká kultura v 19. století. „Slavme slavně slávu Slávóv slavných“. Praha: KLP, 2006.

REITTEREROVÁ, Vlasta. Dvě první vídeňské Prodané nevěsty a jejich představitelé / Theater an der Wien 1893, Hofoper 1896/. Musicalia, 2016, č. 1-2, s. 22-36).

SÉQUARDTOVÁ, Hana. Sto let Smetanova tvůrčího odkazu. In Kuna 1985, s. 105-112.

SCHMORANZ, Gustav. Dvacátý rok Národního divadla 1902-1903. Praha: Nakladatelství Národního divadla, 1903.

[SMETANA, Bedřich]. Veřejný život hudební v Praze. I. Opera. Národni listy, 15. 7. 1864, roč. 4, č. 190 , s. 1 .

STECKER, Karel. K otázce Smetanismu a Wagnerianismu. Praha: Nákladem vlastním, 1911.

STECKER, Karel. Otakar Hostinský a jeho význam pro tvorbu Bedřicha Smetany. Praha: Fr. A. Urbánek, 1912.

ŠALDA, František Xaver. Poznávání Smetany. Venkov, 20. 1. 1918, roč., 13, č. 18, s. 2-3.

ŠALDA, František Xaver. Mladá hudební generace v Čechách. In Kritické projevy 3. Praha: Melantrich, 1950, s. 231-232. Stat původně vyšla In Die Zeit. Wiener Wochenschrift für Politik, Volkswirtschaft, Wissenschaft und Kunst, 6. 3. 1897, Bd. 10, Nr. 127, s. 154-156.

ŠUBERT, František Adolf. České Národni divadlo na prvni mezinárodni divadelni výstavě ve Vídni r. 1892. Sepsal a sestavil Fr. A. Šubert, Praha 1892.

ŠUBERT, František Adolf. K výpravě Národního divadla do Vídně roku 1892. Dalibor, 1909, roč. 31, č. 29-36, s. 48.

ŠUBERT, František Adolf. Feuilleton Smetanovský. Národni politika, 29. 4. 1915, roč. 33, č. 118, s. 2-3.

tt. Česká opera. Hudebni listy, 1874, roč. 5, č. 16. s. 68.

VIKTOROVÁ, Kateřina. Recepce Smetanových oper v éře Karla Kovařovice. Opus musicum, 2018, roč. 50, č. 6, s. 6-37.

X. Zpěv Přemysla. Dalibor, 1874, roč. 2, č. 6. s. 44-45.

WAISAR, Alfons. Soupis pozůstalosti Bedřicha Smetany. In Zprávy Společnosti Bedřicha Smetany 1, Praha: nákladem Společnosti Bedřicha Smetany, 1931-1932, s. 38-52.

[ZELENÝ, Václav Vladimír]. První rok v Národním divadle. Dalibor, 1884, roč. 6, č. 44, s. 433-434.

[?] Zprávy z Prahy a z venkova. Dalibor, 1874, roč. 2, č. 33, s. 262.

[?] Zprávy domácí a z venkova. Hudebni listy, 1874, roč. 5, č. 34, s. 138. 
[?] Vom böhmischen Theater. Belehrendes und Unterhaltendes. II. Politik, 13. 9. 1874, roč. 13, č. 251, s. [2].

[?] Oslava 50. výročí prvního provozování „Prodané nevěsty“. Národni listy, 31. 5. 1916, roč. 56, č. 150, s. 3 .

[?] Program jubilejních slavností Bedřicha Smetany. Smetana, 1923, roč. 13, č. 7-8, s. 97-99.

[?] Mezinárodní hudební festival 1924. Listy Hudebni Matice, 1924, roč. 3, č. 8, s. 300-301. 